\title{
The Impacts of Harmonization of Technical Barriers to Trade (TBT) in ASEAN on the Productivity Growth of Indonesia's Electronics Firms
}

\author{
Fitria Rachmawati \\ Graduate Program in Economics, Department of Economics \\ Faculty of Economic and Business, University Indonesia \\ Depok, Indonesia \\ fitriarachmawati02@gmail.com
}

\author{
Andi Fahmi \\ Department of Economics \\ Faculty of Economic and Business, University Indonesia \\ Depok, Indonesia \\ afahmi91@gmail.com
}

\begin{abstract}
The openness in Free Trade era changes the policy of international trade. Along with the tariff reduction, the use of Technical Barriers to Trade (TBT) increases and is considered as a trade barrier. Assuming that the implementation of TBT harmonization policy has made ASEAN market more integrated, this research aims to estimate the impacts of ASEAN standard harmonization on the firms's productivity growth in electronics industry. Using the firms' data of electronics industry during 20052014 based on BPS "Large Medium Industry survey" and the Generalized Least Square (GLS) method, empirical evidence shows that when ASEAN standard harmonization increases by 1 unit, it increases firms' productivity growth in the electronics sector by 13 , $8 \%$.
\end{abstract}

Index Terms-Technical Barriers to Trade; ASEAN Harmonization; Productivity; Electronics Firms.

\section{INTRODUCTION}

Trade liberalization is still an interesting topic to be discussed despite many researches on it. This is due to the rapid development of international trade market by the increasing number of Economic Integration Agreements (EIA). One of the purposes of EIA is to reduce tariff rates and traditional non-tariff barriers, while Non-Tariff Measures (NTMs) in the form of technical regulation is still allowed for reasons of security and public health and also environment. There are two main categories of technical regulation, Sanitary of Phytosanitary (SPS) and Technical Barriers to Trade (TBT). SPS covers regulations and restrictions to protect human, animal and plant health, while TBT includes technical regulations, standards and procedures related to imported products. Recently, TBT is the most commonly used technical regulations. Most of countries are applying about 30 percent TBT and 15 percent SPS of all traded products and there is also an increasing number of WTO TBT notification database in line with the tariff reducing $0 \%$ in many EIA [1].

As more countries use TBT, studies on the impacts of TBT on trade become very interesting. There are two opinions about TBT, most of the studies show that TBT has negative impact to trade through increasing fixed cost (adaptation cost for market research or regulation and standards cost in foreign country when entering an overseas market as in [2], [3], [4], [5], and [6].

Differences in fixed entry costs that arise in facing different TBT in each country would make international trade become uncompetitive. Reference [7] stated that one of the ways to reduce those constraints is harmonizing standards in each country, so there is only one commonly used standard. The same was also mentioned in [8] and [9] describing a country-specific standard or national standard could promote trade by becoming an international standard. The harmonization of standard is one policy applied in economic integration area such as EU and ASEAN. This policy not only can reduce constraints but also can create a wider market, as in [10] who proved that economic integration could reduce the company's market power and increase productivity through the elimination of non-tariff barriers.

The study on TBT harmonization is still very few in number, and mostly held in developed countries as in [11], [12], [13], [14], [15], [16], [17], [18] except [19] in Africa and [20] in Morocco. In general all studies conducted to see the impacts of TBT harmonization on trade. Furthermore, there are very limited researches about the impacts of TBT harmonization to productivity applied in EIA. Reference [13] resulted that EU harmonization in the Dutch food processing industry increased firm productivity about 4,8\% and [20] showed that when EU harmonization increased 1 unit, productivity of labor would increase about $18.85 \%$. So far, no similar studies have been found on ASEAN regional. This study will be a preliminary study to identify the impacts of ASEAN TBT harmonization on the growth of firms' productivity in Indonesian electronics industry.

\section{LITERATURE REVIEW}

This study refers to the conceptual framework of economies of scale to explain the impacts of ASEAN TBT harmonization on firm productivity in the electronic industry as in [21]. An economy of scale is a concept whereby larger companies or industries with scale of economies will be more efficient, because producers can reduce the average cost per unit of output. 


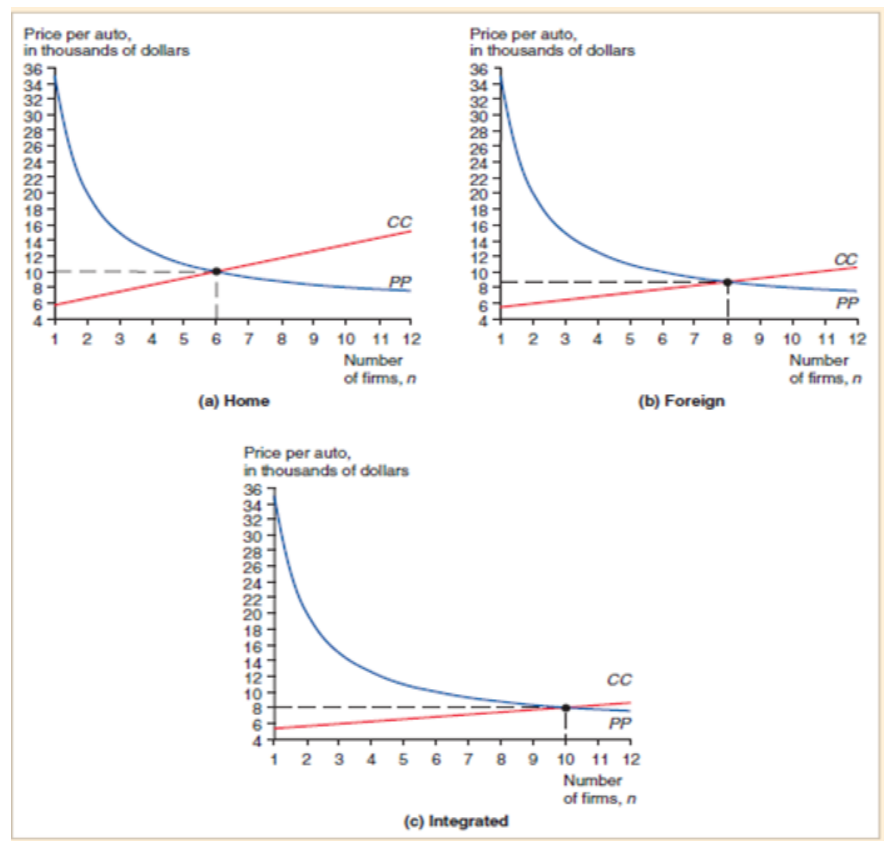

Fig. 1. Equilibrium in Integrated Market [21]

Fig. 1 represents differences between home country and foreign country before and after integration with assumption monopolistic competition. The monopolistic competition model can be used to show the effects of combined market. Before integration, number of firms in home country is less than in foreign country; while, price in home country is higher than in foreign country. This implies average cost in home country is higher than average cost in foreign country. After integration of two markets, number of firms in the market is a combination among firms in both home and foreign countries. But the number of firms is reduced because there are few firms exit from integrated market inducing the increase of market size. Firms will produce more; the price in integrated market is less than price in home and foreign countries. It decreases the average cost of firms than before the integration. By increasing the scale of production, producers can reduce the average cost per unit of output. In other words, the more production is the more efficient; and the average cost decreases as productivity increases.

Several empirical studies on TBT harmonization is conducted such as [12] that examined the impacts of MutualRecognition Agreements (MRA) and TBT harmonization on OECD's member states and non-members. The analysis included North-North, North-South and South-South agreements and used two-stage gravity estimates for 2 sectors: telecommunication equipment and medical devices. From the study it was found that mutual-recognition agreements significantly increased the likelihood and value of trade among member countries. Another interesting thing is that developed countries (third parties) outside integrated market also gained benefit from this harmonization while the same things didn't happen in developing countries. In addition, a similar study was also conducted to distinguish MRA and harmonization but it took the research object in EU countries as in [22]. Reference
[19] used a gravity model to see the impacts of EU standards harmonized with international standards (proxied with ISO) on export volumes in Africa. It showed empirical evidence of a negative relationship between ISO and African export volume to Europe. This supports the results of previous researches as in [12] and [23] that there were differences in the impacts of TBT harmonization in developed countries and developing countries.

Further researches on the impacts of TBT harmonization lead to more specific objects; one of those sees the impacts of the policy on the industrial sector. Reference [11] conducted a study on the impacts of food regulatory harmonization on the single market EU (intra-EU trade) from 1990-2001 at the subsector level and aggregate food industry by using a model based on the gravity model to measure trade. The regression results showed that the EU harmonization on food regulations positively affected the intra-EU trade in aggregate in the food industry sub-sector. Another study examined the influence of harmonization of EU standards on electronic exports from the US using gravity model and import export data. As mentioned in [16], the empirical results found that industries with standard harmonization and more tariff reductions eventually increased the US electronics exports to the EU. This result is in contrast to the results found in [19], and reinforces that there can be differences in the impacts of standards harmonization between developed and developing countries.

A study about the impacts of TBT harmonization on productivity in industry sector was conducted to see the impact of harmonizing EU food product standards on the productivity of the food industry sector in the Netherlands. This study represented EU harmonization impacts on productivity through markup mechanisms, where increasing EU harmonization led to increasing competition (low markup) and improved TFP growth. This study used company and year panel data and the estimates applied Generalized Least Square (GLS). The result showed a positive impact of EU harmonization on productivity which gained $4.8 \%$ when harmonized product coverage increased by 1 unit as mentioned in [13]. Reference [20] also examined the impacts of EU regulatory harmonization on firms' productivity in Morocco, and found similar result with [13] and [14]. The harmonization can affect market structure and then affect competition and markup. The difference between their studies lies on constructing models and harmonization variable. Harmonization variable is obtained from the amount of harmonization applied to the company as in [20], while [13] used production weighted coverage ratio of industrial sector as harmonization variable. Study in Morocco was estimated using fixed effect model and gave positive and significant result. As mentioned in [20], the increase in harmonization by 1 unit would increases labor productivity by $18.85 \%$. Furthermore, the harmonization of TBT in Morocco encouraged Moroccan firms to improve their efficiency in machines or production process that impacts on labor productivity. In addition, Moroccan companies also applied higher markups after harmonization; this is in line with the need to finance investment. 


\section{RESEARCH METHODOLOGY AND DATA}

The model specification used in this research is the development of the model specification used by [13] and [14]. There are two stages in analyzing the impacts of TBT harmonization on productivity:

a. First stage is estimating TFP from translog production function.

$$
\begin{gathered}
\ln y_{i t}=\beta_{0}+\beta_{1} \ln k_{i t}+\beta_{2} \ln l_{i t}+\beta_{3}\left(\ln k_{i t}\right)^{2}+ \\
\beta_{4}\left(\ln l_{i t}\right)^{2}+\beta_{5} \ln k_{i t} \ln l_{i t}+\varepsilon_{i t}
\end{gathered}
$$

where:

$$
\begin{array}{cc}
\ln y_{i t}: & \begin{array}{l}
\text { Natural logarithm value added firm } \mathrm{i} \text { at } \\
\text { year } \mathrm{t}
\end{array} \\
\ln k_{i t}: \begin{array}{l}
\text { Natural logarithm number of labor firm } \mathrm{i} \text { at } \\
\text { year } \mathrm{t}
\end{array} \\
\ln l_{i t}: \begin{array}{l}
\text { Natural logarithm capital (proxied with } \\
\text { electricity consumption) firm } \mathrm{i} \text { at year } \mathrm{t}
\end{array}
\end{array}
$$

TFP is the residual of the production function, where the estimated productivity of firm $\mathrm{i}$ is calculated as a residual combination known only to the company $\left(\beta_{0}\right)$ and residual unobservable $\left(\varepsilon_{i t}\right)$. The expected parameter values are $\beta_{1}>0$ dan $\beta_{2}>0$. Thus, after obtaining the coefficient value of each variable of the production function, the natural logarithm of TFP (ln TFP) of each firm $i$ in year $t$ can be calculated by the following equation:

$$
\begin{gathered}
\ln T F P_{i t}=\ln y_{i t}-\beta_{1} \ln k_{i t}-\beta_{2} \ln l_{i t}-2 \beta_{3} \ln k_{i t}- \\
2 \beta_{4} \ln l_{i t}-\beta_{5} \ln k_{i t} \ln l_{i t}
\end{gathered}
$$

This study uses TFP with several empirical constraints, namely the possibility of simultaneity of bias and second selection bias as in [24]. Therefore measurements with ordinary least squares (OLS) is not recommended because it could cause significant estimation bias, and could ultimately lead to an estimated value of productivity, also be biased as mentioned in [24], [25], and [26]. Furthermore, [24] mentioned that by assuming the productivity of a company is plantspecific, but time-invariant, the estimation of the above production function can be done using fixed effect method.

b. Second stage is estimating the impacts of the TBT harmonization on growth of productivity in the electronics industry firms in Indonesia.

The empirical model is:

$$
\begin{gathered}
\ln \text { TFP }_{i t}=\beta_{0}+\beta_{1} \ln \text { HARM }_{i t}+\beta_{2} \text { dummyekspor }+ \\
\beta_{3} \ln \text { HARM }{ }_{i t} \text { Xdummyekspr }+\beta_{4} \ln \text { EmploySize }+ \\
\beta_{5} \ln H H I+\beta_{6} \text { dummyforeignowner }+ \\
\beta_{7} \text { dummycrisis }+\varepsilon_{i t}
\end{gathered}
$$

where:

$\ln T F P_{i t}$

$$
\text { : Firm productivity of firm } i \text { at year } t
$$

$\ln H A R M_{\text {it }}$

dummyekspor

In HARM ${ }_{i t}$ Xdummyekspr : Interaction variable between $\operatorname{lnHARM}_{\mathrm{it}}$ with dummyekspor, to see whether the impact of the TBT harmonization differs between exporting firms and not.

ln EmploySize

$\ln H H I$

dummyforeignowner : This variable which is worth 1 (one) if PMA, 0 (zero) if otherwise. This variable is as a proxy to see technological advances where firms with foreign capital usually have higher technology than domestic companies.

dummycrisis

: This variable which is worth 1 (one) for 2007 - 2009, 0 (zero) if otherwise. This variable is used to see the effect of crisis on productivity.

To measure the effects of ASEAN TBT harmonization in the electronic industry, [13] is adopted to create electronic product database consisting of product that have and have not implemented. There is about $21,13 \%$ electronic products covered by ASEAN TBT harmonization. Products covered by harmonization are given value 1 and 0 if otherwise in year $t$. This value is summed up to make a coverage ratio of TBT harmonization for electronic sector. A comparative number is taken between firm i' s production and total firms production in electronic sector as production-weighted. Both of coverage ratio and production-weighted are multiplied to get a variable to absorb the effect of TBT harmonization on firms' productivity.

This research addresses the productivity growth measurement, ASEAN TBT harmonization, EmploySize and Herfindahl index using unbalanced panel data from the Annual Survey of Manufacturing Firms (SI) data for the years 2005-2014 based on the Indonesian Statistical Agency (BPS). Panel data have some advantages according [27] such as controlling individual heterogeneity, more informative data, variatif, reduce collinearity between variables and higher 
degrees of freedom. In this study, econometric analysis is used to estimate the impacts of harmonization of TBT on productivity. There are three kinds of approaches in the analysis of panel data model: least squares (OLS), fixed effect (FE) and random effect (RE) approach. The testing results, using classical assumption of Breusch Pagan test, show that there is a heteroskedastis problem. One way to overcome this is by using Weighted Least Square (WLS) or Generalized Least Squares (GLS) method. Selection of GLS method is in addition to eliminate the heteroskedasticity also autocorrelation so that the estimation process becomes efficient, unbiased and consistent as in [27].

\section{REGRESSION RESULT}

In this study, FE and GLS methods are used to estimate the impacts of ASEAN TBT harmonization on the productivity of the electronic firms. The GLS is chosen because it is considered as more advanced than OLS, while FE is selected after fulfilling Hausmann test. Before estimating the impacts of TBT harmonization, first, the production function of translog was estimated using unbalanced panel dataset during the periode of $2005-2014$ using FE. The coefficient value of each variable is used to calculate TFP obtained as residual of production function. The regression results show statistically significant at the level of $1 \%$ and $5 \%$ (table 1 ).

\section{TABLE I. REGRESSION RESULT OF PRODUCTION FUNCTION}

\begin{tabular}{|c|c|c|}
\hline $\begin{array}{c}\text { Variable } \\
\text { Dependent }\end{array}$ & $\begin{array}{c}\text { TFP } \\
(\text { OLS })\end{array}$ & $\begin{array}{c}\text { TFP } \\
(\mathrm{FE})\end{array}$ \\
\hline $\ln k_{i t}$ & $0.363^{* * *}$ & $0.503^{* * *}$ \\
$(11.40)$ & $(11.07)$ \\
\hline \multirow{2}{*}{$\left(\ln k_{i t}\right)^{2}$} & $0.0263^{* * * *}$ & $0.0191^{* * *}$ \\
$(7.59)$
\end{tabular}

$\mathrm{t}$ statistics in parentheses

$* \mathrm{p}<0.05, * * \mathrm{p}<0.01, * * * \mathrm{p}<0.001$

The value obtained from the production function regression is then used for TFP calculation. TFP is used to estimate the impact of ASEAN TBT harmonization on firm productivity. The result is shown in the table below (table 2) with FE and GLS methods.
TABLE II. REGRESSION RESULT

\begin{tabular}{|l|c|c|}
\hline \multicolumn{1}{|c|}{ Variable Dependent } & $\begin{array}{c}\ln T F P_{i t} \\
(\mathrm{FE})\end{array}$ & $\begin{array}{c}\ln T F P_{i t} \\
(\mathrm{GLS})\end{array}$ \\
\hline \multirow{2}{*}{$\ln$ HARM } & $\begin{array}{c}0.126^{* * *} \\
(12.42)\end{array}$ & $\begin{array}{c}0.138^{* * *} \\
(25.52)\end{array}$ \\
\hline \multirow{2}{*}{ dummyekspor } & $\begin{array}{c}0.544^{* * *} \\
(6.43)\end{array}$ & $\begin{array}{c}0.0546 \\
(0.69)\end{array}$ \\
\hline \multirow{2}{*}{$\ln$ HARM ${ }_{\text {it }}$ Xdummyekspr } & $0.0861^{* * *}$ & $0.0591^{* * *}$ \\
& $(5.06)$ & $(4.33)$ \\
\hline $\ln$ EmploySize & -0.0645 & $0.214^{* * *}$ \\
& $(-1.47)$ & $(14.53)$ \\
\hline $\ln$ HHI & $-0.338^{* *}$ & $-0.867^{* * *}$ \\
& $(-2.97)$ & $(-9.35)$ \\
\hline dummyforeignowner & -0.203 & $0.284^{* * *}$ \\
& $(-1.58)$ & $(7.53)$ \\
\hline dummycrisi & $-0.564^{* * *}$ & $-0.420^{* * *}$ \\
& $(-13.62)$ & $(-14.52)$ \\
\hline cons & $3.968^{* * *}$ & $5.687^{* * *}$ \\
& $(17.42)$ & $(11.51)$ \\
\hline $\mathrm{N}$ & 7247 & 7247 \\
\hline
\end{tabular}

t statistics in parentheses

$* \mathrm{p}<0.05, * * \mathrm{p}<0.01, * * * \mathrm{p}<0.001$

Having applied the FE methods showed significant positive results for $H A R M_{i t}$ and dummyekspor and significant negative results for $H H I$ and dummycrisis. On the other hand, GLS showed significant positive results for $H A R M_{i t}$ and EmploySize, dummyforeignowner and interaction between $H A R M_{i t}$ and dummyekspor; while the results are significantly negative for HHI and dummycrisis. For dummyekspor there is no significant effect on productivity growth. Since there are more significant variables, the preferred method chosen is GLS.

$H_{A R M}$ it is a production-weighted coverage ratio that is created to capture the effects of ASEAN harmonization on all domestic firms. GLS showed significant positive results; the increasing product coverage harmonized with ASEAN electronic standards by 1 unit would increase productivity growth by $13.8 \%$. This indicates that the unified market through the use of the same TBT (standards) can increase the firms' productivity growth in electronics industry. The interaction between HARM $M_{i t}$ and dummyekspor gives a significant positive result. These results suggest that the impacts of TBT harmonization on productivity depend on firms that export and do not export. This study found that harmonization by exporting firms has a higher impact on productivity growth than non-exporting firms.

EmploySize shows significant positive results affecting growth increase of 21, 4\% when EmploySize increases 1 unit. These results indicate that as the company grows larger it will increase the productivity growth; since large companies will have economies of scale and are more efficient. Large companies produce more output with the same inputs as earlier. Another control variable that also significantly and positively affects is dummyforeignowner. A firm with foreign ownership (PMA) could increase productivity growth by $28.4 \%$ higher than non-PMA firms. PMA firms are assumed 
to have more sophisticated technology, better management, and larger production capacities; make them more efficient and have higher productivity than domestic firms.

\section{CONCLUSION}

This study aims to estimate the impacts of ASEAN TBT harmonization on the firms' productivity in electronic industry in Indonesia. Similar studies have not been done so much in developing countries and it is a preliminary study that sees the impact of the harmonization of Technical Barriers to Trade in ASEAN. From the analysis, it was found that the harmonization of ASEAN standards had a significant positive impact on the firms' productivity growth in the Indonesian electronics industry. A 1 unit increase of the harmonized product coverage could increase productivity growth by $13.8 \%$. This study also found that the size of firms - proxied with employment, and the advances in technology - proxied by foreign ownership (PMA) have a significant positive impact on productivity growth. The larger firms could produce more by utilizing the economies of scale. Furthermore, the use of more advanced technology will make the company more efficient and bring ultimate increase in productivity.

The dummyekspor shows insignificant results, this is contrary to the existing theory. Allegedly this result is due to only few firms (about $25 \%$ of total firms) do exporting in the electronics sector. Types of products and export destinations have not been addressed yet, since not all types of electronic products are harmonized. However, when dummyekspor interacted with harmonized variables, HARM $M_{i t}$, it made significant positive result; it showed that the impacts of harmonization on productivity depend on the exporting and non-exporting firms.

\section{REFERENCES}

[1] M. Fugazza, "The economics behind non-tariff measures: Theoretical insights and empirical evidence," UNCTAD Policy issues in international trade and commodities study series no. 57, 2013.

R.E. Baldwin, J. McLaren and A. Panagariya, "Regulatory protectionism, developing nations, and a two-tier world trade system," Brookings Institution Press, pp.237-293, 2000.

M. Ganslandt and J.R. Markusen, "Standards and related regulations in international trade: A modelling approach," NBER Working Paper Series, 2001.

M.X. Chen and A. Mattoo, "Regionalism in standards: Good and bad for trade?," The Canadian Journal Economics, vol.41, no.3, pp.838-863, 2008.

J.E. Anderson and E. Wincoop, "Trade costs," Journal of Economic Literature, vol.XLII, pp.691-751, 2004.

R.E. Baldwin and R. Forslid, "Trade liberalization with heterogeneous firms," Review of Development Economics, vol.14, no.2, pp.161-176, 2010

[2] J. Michalek, "Comparative analysis of importance of technical barriers to trade (TBT) for central and eastern european countries' and mediterranean partner countries' exports to the EU," FEMISE Research no. FEM 22-03, 2005.

[3] J. Moenius, "Information versus product adaptation: The role of standards in trade," Social Science Research Network, 2004.

[4] G.M.P. Swann, "International standards and trade: A review of the empirical literature," OECD Trade Policy Papers, no. 97, 2010.
[5] A. Botasso and A. Sembenelli, "Market power, productivity and the EU single market program: Evidence from a panel of italian firms," European Economic Review, no.45, pp167-186, 2001.

[6] B. de Frahan and M. Vancauteren, "Harmonisation of food regulations and trade in the single market: evidence from disaggregated data," European Review of Agricultural Economics, vol.33, no.3, pp337-360, 2006.

[7] S. Baller, "Trade effects of regional standards liberalization: a heterogeneous firms approach," World Bank Policy Research Working Paper, no.4124, pp.1-44, 2007.

[8] M. Vancauteren and B. de Frahan, "Trade policy, competition and productivity: The impact of EU harmonization in the dutch food processing industry," De Economist, vol. 159, no. 4, pp483-509, 2011.

[9] M. Vancauteren, "EU harmonisation of regulation and mark-ups in the dutch food industry," European Review of Agricultural Economics, vol.40, no.1, pp163-189, 2012.

[10] M. Vancauteren, "The role of EU harmonization in explaining the export-productivity premium of food processing firms," Frontiers of Economics and Globalization, Vol.12, pp.165-185, 2013.

[11] JD. Reyes, "International Harmonization of Product Standards and Firm Heterogeneity in International Trade," World Bank Working Paper No. 5677,2011

[12] A. Portugal-Perez, JD. Reyes and J.S Wilson, "Beyond the information technology agreement: Harmonisation of standards and trade in electronics," The World Economy, pp. 1870-1897, 2010.

[13] B. Shepherd, "Product standards and export diversification," Journal of Economic Integration, vol. 30, no. 2, pp.300-333, 2015.

[14] W. Czubala, B. Shepherd and J.S. Wilson, "Help or hindrance? The impact of harmonised standards on african export," Journal of African Economies, vol. 18, no. 5, pp.711-744, 2009.

[15] P. Augier, O. Cadot and M. Dovis, "Regulatory harmonization, profits and productivity: Firm-level evidence from Morocco," Ferdi Working Paper, 2016.

[16] P.R. Krugman and M. Obstfeld, "International economics: theory and policy," $6^{\text {th }}$ Edition, Harper Collins College Publisher, New York, 2006.

[17] M. Chen and A. Mattoo, "Regionalism in standards; good or bad for trade?," The Canadian Journal of Economics, vol.41, no.3, pp.838-863, 2008.

[18] T. Otsuki, J. Wilson and M. Sewadeh, "What price precaution? European harmonisation of aflatoxin regulations and African groundnut exports," European Review of Agricultural Economics, vol.28, no.2, pp.263-283, 2001.

[19] I. Van Beveren, "Total factor productivity estimation: A practical review," Journal of Economic Surveys, vol. 26, no.1, pp.98-128, 2010.

[20] J. Levinsohn and A. Petrin, "Estimating production functions using inputs to control for unobservables," The Review of Economic Studies, vol. 70, no. 2, pp.317-34, 2003.

[21] J. Van Biesebroeck, "Robustness of Productivity Estimates," The Journal of Industrial Economics, vol. LV, no.3, 2007.

[22] D.N Gujarati, "Basic econometrics," $5^{\text {th }}$ Edition, New York: McGraw Hill International Edition, 2009. 